\title{
PENDIDIKAN BUDI PEKERTI DI SEKOLAH
}

\author{
${ }^{1)}$ Musa Pelu, ${ }^{2)}$ Achmad Dardiri, ${ }^{3)}$ Darmiyati Zuchdi \\ ${ }^{1)}$ Universitas Sebelas Maret Surakarta, ${ }^{2,3}$ Universitas Negeri Yogyakarta \\ 1)pelumusa@yahoo.com, ${ }^{2)}$ achmaddardiri@uny.ac.id, ${ }^{3)}$ darmiyatiz@yahoo.com
}

\begin{abstract}
Abstrak
Penelitian ini bertujuan menggambarkan pemberdayaan modal sosial dan modal budaya dalam pelaksanaan Kurikulum Pendidikan Budi Pekerti di SMP Muhammadiyah 5 Surakarta dan SMP Kasatriyan 1 Surakarta.Penelitian ini bersifat deskriptif kualitatif dengan pendekatan naturalistik. Penelitian dilakukan di SMP Muhammadiyah 5 Surakarta dan SMP Kasatryan 1 Surakarta. Pengumpulan data dilakukan dengan wawancara mendalam, observasi, dan analisis dokumen. Instrumen penelitian adalah peneliti sendiri sebagai pengumpul data. Untuk memperoleh derajad validitas tinggi, digunakan teknik trianggulasi, recheck, dan peerdebriefing. Analisis penelitian dilakukan dengan teknik analisis interaktif yang meliputi tahapan pengumpulan data, reduksi data, sajian data, dan verifikasi/menarik kesimpulan. Kesimpulan penelitian ini adalah sebagai berikut. (1) Jaringan kerja sama yang sinergis dilandasi rasa percaya dan kesamaan nilai/norma merupakan modal sosial yang telah dimanfaatkan dan diberdayakan dalam rangka mendukung pelaksanaan kebijakan kurikulum pendidikan budi pekerti di SMP Muhammadiyah 5 Surakarta dan SMP Kasatriyan 1 Surakarta. (2) Kultur sekolah berbasis budi pekerti dan agama di SMP Muhammadiyah 5 Surakarta dan kultur sekolah berbasis budi pekerti dan multikultural serta kultur komunitas merupakan modal budaya utama yang dimanfaatkan dan dikelola dalam pelaksanaan Kurikulum Pendidikan Budi Pekerti.
\end{abstract}

Kata kunci: pendidikan budi pekerti, modal sosial, modal budaya

\section{THE MANNERS EDUCATION IN THE SCHOOL}

\author{
${ }^{1)}$ Musa Pelu, ${ }^{2)}$ Achmad Dardiri, ${ }^{3)}$ Darmiyati Zuchdi \\ ${ }^{1)}$ Universitas Sebelas Maret Surakarta, ${ }^{2,3)}$ Universitas Negeri Yogyakarta \\ 1)pelumusa@yahoo.com, ${ }^{2)}$ achmaddardiri@uny.ac.id, ${ }^{3)}$ darmiyatiz@yahoo.com
}

\begin{abstract}
The study was to describe the social capital and the cultural capital empowerment in the implementation of Manners Education Curriculum in the Muhammadiyah 5 Surakarta Junior High School and the Kasatriyan 1 Surakarta Junior High School. The study was a descriptive qualitative research with a naturalistic approach. The study was conducted in the Muhammadiyah 5 Surakarta Junior High School and the Kasatriyan 1 Surakarta Junior High School. The data gathering was conducted by performing in-depth interview, observation and document analysis. The research instrument in the study was the researcher himself as the data gatherer. In order to attain a high validity degree, the researcher also implemented the triangulation, the recheck and the peer debriefing technique. The data analysis was conducted by performing the interactive data analysis that included the following stages: data gathering, data reduction, data display and verification/conclusion drawing. The conclusions of the study then are as follows: (1) the synergic network of cooperation that has been based on the trust and the similarity of values and norms becomes the benefitted social capital and are empowered in order to support the implementation of manners education curriculum in the Muhammadiyah 5 Surakarta Junior High School and the Kasatriyan 1 Surakarta Junior High School; and (2) the manners and religion-based school cultures in the Muhammadiyah 5 Surakarta Junior High School and the manner and multiculturalism-based school culture altogether with the community culture are the main cultural capital that has been benefitted in the implementation of Manners Education Curriculum.
\end{abstract}

Keywords: manners education, social capital, cultural capital 


\section{PENDAHULUAN}

Kota Surakarta atau yang lebih dikenal dengan Kota Solo, mayoritas masyarakatnya adalah orang Jawa, diikuti dengan orang Tionghoa, keturunan Arab, Banjar, Madura, dan sebagian kecil dari berbagai daerah di Indonesia. Masyarakat Surakarta merupakan masyarakat majemuk yang secara horizontal terdiri dari beberapa etnik, ras, agama, ideologi, dan budaya; dan secara vertikal terdiri dari beberapa lapisan atau kelas sosial-ekonomi dan porsi kekuasaan terbesar yang dimiliki oleh seseorang maupun suatu kelompok.

Dalam masyarakat dengan polarisasi sosial yang tajam seperti masyarakat Kota Surakarta, maka tidak dapat dipungkiri bahwa dalam sejarahnya, di Kota Surakarta sering terjadi berbagai konflik sosial terutama pada abad ke-20, yang membuatnya identik dengan budaya kekerasan.

Solo adalah sebuah fenomena yang mengandung keunikan, kontradiktif, dan kontroversial. Adanya kerusuhan massal (Solo Kelabu), tanggal 14-15 Mei 1998, di tengah kota yang dirumuskan sebagai "Kota Budaya" perilaku kekerasan terjadi di pangkuan budaya adiluhung. Kerusuhan yang berlangsung sekitar 40 jam tersebut, merupakan kerusuhan terbesar tidak saja selama masa Orde Baru tetapi juga dalam sejarah sosial Surakarta. Peristiwa kerusuhan tersebut juga yang kesebelas kalinya menimpa Kota Surakarta. Besarnya kerusuhan dapat dilihat dari luasnya area kerusuhan, lamanya peristiwa, jumlah massa yang terlihat, berbagai akibat kerusuhan massal (kerusakan lingkungan fisik dan kerugian harta benda), pengalaman traumatik bagi warga yang terkena akibatnya secara langsung, dan dampak sosial-ekonomi karena peristiwa tersebut. Peristiwa kerusuhan tersebut terjadi dalam bentuk perusakan, pembakaran, penjarahan harta benda, penganiayaan, dan bahkan pemerkosaan.

Berselang satu tahun berikutnya, tepatnya pada bulan November 1999, di Kota Surakarta kembali terjadi aksi kerusuhan massal yang diikuti dengan tindakan pembakaran terhadap gedung Balai Kota Surakarta serta perusakan terhadap sarana dan fasilitas umum lainnya. Kerusuhan itu dipicu oleh kekalahan Megawati Soekarno Putri dalam pemilihan presiden lewat pemungutan suara dari anggota MPR.
Kedua peristiwa kerusuhan tersebut, mengindikasikan adanya tindakan kekerasan yang seolah-olah sudah menjadi perilaku umum atau budaya. Ironisnya, perilaku kekerasan tersebut banyak melibatkan para pemuda terutama pelajar. Dilain pihak, aksi kekerasan tersebut menimbulkan sebuah pertanyaan besar yaitu bagaimana mungkin kerusuhan dengan tingkat kuantitas tinggi bisa terjadi pada masyarakat yang memiliki kultur halus dengan nilai-nilai budaya Jawanya yang mementingkan prinsip kerukunan dan prinsip hormat melakukan tindakan yang sadis dan amoral-asusila.

Visi Kota Surakarta sebagai kota budaya sekaligus kota pelajar hanya akan menjadi sebuah slogan tanpa makna, apabila tidak ada penanganan yang serius, terprogram, dan menyeluruh untuk mengatasi aksi kekerasan tersebut. Untuk itulah, Dinas Dikpora Kota Surakarta bekerja sama dengan UNICEF dan Pemerintah Kota Surakarta mencoba memformulasikan proses Pendidikan Budi Pekerti sebagaimana tertuang dalam konsep materi Pendidikan Budi Pekerti dalam kurikulum sekolah di SMP Kota Surakarta. Pada tahun 2005, kebijakan ini sudah mulai diberlakukan untuk semua SMP di Kota Surakarta. Kebijakan ini merupakan salah satu langkah preventif untuk mengatasi budaya kekerasan sebagai indikasi kemerosotan moral di Kota Surakarta (Pemerintah Kota Surakarta \& UNICEF, 2004, pp. i-ii).

Dalam rangka mengatasi budaya kekerasan dan masalah kemerosotan moral, sebenarnya masyarakat Kota Surakarta telah memiliki modal sosial dan modal budaya yang positif yang memungkinkan masyarakatnya bekerja sama untuk mencapai tujuan yang diharapkan. Modal sosial dan modal budaya tersebut, terdapat dalam budaya masyarakat Surakarta yang menjungjung tinggi nilai-nilai budaya Jawa yang mengutamakan prinsip kerukunan dan prinsip hormat. Kedua prinsip ini merupakan kerangka normatif yang menentukan bentuk-bentuk konkret semua interaksi. Prinsip rukun bertujuan mempertahankan masyarakat dalam keadaan yang harmonis, yaitu dalam keadaan selaras, tenang dan tenteram, tanpa perselisihan dan pertentangan. Prinsip hormat memainkan peranan yang sangat besar dalam mengatur pola interaksi dalam masyarakat Jawa. Prinsip ini menunjuk 
pada sikap hormat terhadap orang lain baik dalam wujud bahasa maupun tindakannya.

Modal sosial itu memiliki beberapa manfaat, baik pada masyarakat, organisasi, maupun individu. Manfaat modal sosial bagi masyarakat antara lain seperti ditunjukkan oleh Putnam bahwa pertumbuhan ekonomi sangat berkorelasi dengan kehadiran modal sosial. Selanjutnya, manfaat modal sosial bagi organisasi, antara lain seperti ditunjukkan dalam penelitian Hartanto yang mengemukakan beberapa preposisi tentang hubungan modal sosial dengan kemajuan organisasi. Sejalan dengan itu, Sulasmi menemukan bahwa semangat kerja sama, rasa saling percaya, berkorelasi dengan intensitas kerja sama yang selanjutnya mempengaruhi kualitas sinergi kerja organisasi (Ancok, 2003, pp.20-22).

Pendapat serupa juga dikemukakan oleh Fukuyama yang menyatakan bahwa modal sosial akan semakin kuat dalam masyarakat yang berlaku norma saling bantu membantu dan kerja sama yang kompak dalam satu ikatan jaringan hubungan kelembagaan sosial. Kepercayaan berkaitan dengan budaya, terutama etika dan moral. Akhirnya, Fukuyama berkesimpulan bahwa tingkat saling percaya dalam suatu masyarakat berkaitan erat dengan nilai-nilai budaya yang dimiliki masyarakat bersangkutan. Dalam hal ini modal budaya berupa nilai-nilai budaya yang dimiliki suatu masyarakat bersama modal sosial akan sangat berpengaruh terhadap tercapainya suatu tujuan yang diharapkan (Fukuyama, 2007, pp.22, 146). Pemanfaatan modal sosial dan modal budaya ini perlu dijadikan perhatian bagi pelaksanaan pendidikan budi pekerti di sekolah sebagai salah satu solusi untuk mengatasi problem kemerosotan moral, termasuk pendidikan budi pekerti di Kota Surakarta. Walaupun modal sosial dan modal budaya memiliki kontribusi bagi upaya perbaikan dan kemajuan organisasi sosial yang memungkinkan manusia bekerja sama untuk mencapai tujuan yang diharapkan, namun peranan modal sosial dan modal budaya dalam pelaksanaan pendidikan budi pekerti belum optimal. Oleh karena itu, perlu dilakukan penelitian mengenai bagaimana peranan modal sosial dan modal budaya dalam pelaksanaan pendidikan budi pekerti di Kota Surakarta yang dikemas dalam judul "Pendidikan Budi Pekerti di Sekolah: Pemberdayaan Modal Sosial dan Modal Budaya".

\section{METODE PENELITIAN}

Penelitian ini bersifat deskriptif kualitatif dengan pendekatan naturalistik. Penelitian dilakukan untuk menggambarkan pemberdayaan modal sosial dan modal budaya dalam mengimplementasikan pendidikan budi pekerti di SMP Muhammadiyah 5 Surakarta dan SMP Kasatriyan 1 Surakarta. Oleh karena itu, penelitian bersifat eksplorasi, yang menjelaskan suatu fenomena yang detail, menyeluruh dan mendalam (Muhadjir, 2011, pp.192, 194).

Penelitian dilakukan di SMP Muhammadiyah 5 Surakarta dan SMP Kasatriyan 1 Surakarta. Penelitian ini menggunakan purposive sampling yaitu teknik penentuan sampel dengan pertimbangan tertentu yang telah ditentukan oleh peneliti. Landasan pemilihan lokasi adalah sebagai berikut. Pertama, SMP Muhammadiyah 5 Surakarta adalah sekolah swasta umum yang berbasis agama Islam yang didirikan oleh organisasi Muhammadiyah; terletak di pinggir jalan besar yang cukup padat yang kental dengan nuansa kota karena dekat kantor pemerintah, swasta, dan pusat perbelanjaan atau mall; siswanya sebagian besar berasal dari keluarga dengan status sosial ekonomi menengah ke bawah dengan tingkat kepedulian orang tua terhadap pendidikan anak kurang; rata-rata nilai UAN SD siswa yang masuk ke SMP Muhammadiyah 5 Surakarta relatif rendah; sebagian besar gurunya belum PNS dan masih muda; sebelum diberlakukannya kurikulum pendidikan budi pekerti tahun 2005, tingkat kenakalan siswa cukup tinggi dan kedisiplinan siswanya cukup rendah.

Kedua, SMP Kasatryan adalah sekolah swasta umum yang didirikan oleh yayasan Kasatryan; terletak di lingkungan sekitar Keraton Kasunanan Surakarta yang identik dengan Budaya Jawanya; rata-rata nilai UAN SD siswa yang masuk juga rendah; warga sekolah cukup beragam dilihat dari status sosial ekonomi, agama dan keyakinan, status kepegawaian guru dan tenaga kependidikan (PNS, guru dan tenaga tetap yayasan, guru dan tenaga tidak tetap) dengan usia yang ratarata sedang; sebelum diberlakukannya kurikulum pendidikan budi pekerti tahun 2005, tingkat kenakalan siswa rendah dan kedisiplinan siswanya cukup baik. Waktu penelitian secara efektif sekitar 4 bulan, yaitu sejak bulan Maret sampai bulan Juni 2015. 
Subjek dalam penelitian ini adalah kepala sekolah, guru, staf administrasi, penjaga sekolah, keamanan sekolah, siswa, pegawai kantin sekolah, orang tua siswa, pengurus yayasan, dan masyarakat sekitar SMP Muhammadiyah 5 Surakarta dan SMP Kasatryan. Khusus dalam penetapan siswa sebagai subjek penelitian, diperhatikan pemerataan kelas, jenis kelamin, dan jenis kasus khusus yang terkait dengan pendidikan budi pekerti siswa. Karena penelitian ini menggunakan pendekatan naturalistik maka penentuan subjek penelitian diambil secara 'purposive sampling', yakni yang dapat memberikan informasi tentang pelaksanaan pendidikan budi pekerti di sekolah. Sampel dapat berupa hal, peristiwa, manusia, situasi yang diobservasi. Sampel berupa informan yang dapat diwawancarai, kemudian dimintai untuk menunjuk orang lain yang dapat memberikan informasi, dan kemudian responden ini diminta pula menunjuk orang lain, dan seterusnya. Untuk memperoleh informasi tertentu, sampling dapat diteruskan sampai dicapai taraf 'redundancy' atau kejenuhan, artinya bahwa dengan menggunakan informan selanjutnya boleh dikatakan tidak lagi diperoleh tambahan informasi baru yang berarti. Teknik penentuan informan secara berkelanjutan tersebut disebut dengan snowball sampling technique, yaitu teknik pemilihan informan yang diawali dari jumlah kecil, kemudian atas dasar rekomendasinya menjadi semakin membesar sampai pada jumlah yang diinginkan. Objek penelitian adalah pendidikan budi pekerti di sekolah.

Teknik pengumpulan data dengan (1) wawancara mendalam, (2) pengamatan langsung, dan (3) analisis isi. Wawancara mendalam (in-dept interview) dilakukan terhadap berbagai informan mulai dari siswa, guru, staf/karyawan tata usaha, kepala sekolah, orang tua siswa, masyarakat sekitar sekolah, dan pengurus yayasan. Proses wawancara mendalam dilaksanakan dengan prosedur wawancara bebas, informal, pertanyaan tidak terstruktur, tetapi memfokus pada masalah, sehingga mencerminkan suasana alamiah yang memungkinkan diperolehnya data yang empirik (Moleong, 2007, p.187). Untuk menghindari pembiasan data, penulis menggunakan alat bantu perekam.

Pengamatan dilakukan dengan cara peneliti secara langsung dalam situasi sosial yang sebenarnya, sehingga penulis mampu menghayati dan menangkap konfigurasi fenomena peristiwa yang terjadi (Lincoln dalam Moleong, 2007, pp.191-192). Peristiwa dan tempat peristiwa yang diamati mencakup perilaku dan suasana interaksi antarsiswa, antara siswa dengan guru, staf/karyawan, dan kepala sekolah, serta interaksi antarguru, guru dengan staf/karyawan, guru dan staf/karyawan dengan kepala sekolah, dan warga sekolah dengan masyarakat sekitar sekolah.

Teknik lain yang digunakan sebagai pendukung melengkapi data, ditempuh dengan menganalisis data dokumentatif/arsiparsip berkenaan dengan peristiwa atau data visual tentang aktifitas yang dilakukan warga sekolah dalam pelaksanaan pendidikan budi pekerti. Menurut Moleong (2007, p.217), dokumen adalah setiap bahan tertulis atau film. Dokumen digunakan dalam penelitian sebagai sumber data karena dalam banyak hal sebagai informasi yang dimanfaatkan.

Instrumen penelitian adalah peneliti sendiri yang bertindak sebagai pengumpul data. Peneliti dalam melakukan pengumpulan data berdasarkan pada kaidah-kaidah dan ketentuan yang berlaku dalam penelitian kualitatif (Nasution, 1992, p.55).

Untuk memperoleh derajad validitas tinggi, dilakukan teknik trianggulasi, recheck dan peerdebriefing (Moleong, 2007, p. 324). Trianggulasi dilakukan dengan cara cross check data-data yang dikumpulkan dari berbagai sumber data (informan,tempat/peristiwa,dokumen/arsip), mengenai masalah yang sama. Sedangkan teknik recheck dilakukan dengan cara menguji hasil data wawancara dari informan yang telah dimintai keterangan, untuk memperkaya dan memantapkan bahwa data hasil wawancara terbukti kesahihannya. Selanjutnya teknik validitas model peer debriefing ditempuh dengan cara mendiskusikan hasil penelitian dengan berbagai personal yang didasarkan atas kemampuan pengetahuan yang serupa. Cara seperti ini memantapkan hasil yang telah diuji dengan argumentasi yang logis, sehingga diperoleh data yang benar-benar valid.

\section{Teknik Analisis Data}

Analisis penelitian dilakukan dengan teknik interaktif (Miles dan Huberman, 1984, pp.21-23). Proses analisis interaktif meliputi tahapan: (1) pengumpulan data, (2) reduksi data, (3) sajian data, dan (4) verifikasi/mena- 
rik kesimpulan. Analisis dilakukan terusmenerus dari awal pengumpulan data sampai dengan betul-betul diperolehnya data hasil penelitian yang lengkap. Dengan demikian, proses analisis terjadi secara interaktif, yang menguji antarkomponen secara siklus yang berlangsung dalam waktu cukup lama, sehingga diperoleh hasil penjelasan yang benarbenar tuntas dan mendalam. Output kegiatan penelitian ini adalah diperolehnya data tentang implementasi pendidikan budi pekerti, modal sosial dan modal budaya yang dikelola dalam mengimplementasikan pendidikan budi pekerti di SMP Muhammadiyah 5 Surakarta dan SMP Kasatryan Surakarta..

\section{HASIL PENELITIAN DAN PEMBAHASAN}

\section{Pemberdayaan Modal Sosial dan Modal Bu- daya di SMP Muhammadiyah 5 Surakarta}

Pemberdayaan Modal Sosial dalam Pelaksanaan Pendidikan Budi Pekerti di SMP Muhammadiyah 5 Surakarta

Berdasarkan teori dinamika kelompok, modal sosial dilihat sebagai suatu kelompok yang memiliki ciri kohesivitas yang tinggi. Ciri kohesivitas dimaksudkan adanya hubungan yang aktif di antara manusia, didasari rasa percaya, saling pengertian dan kesamaan nilai dan perilaku yang mengikat anggota dalam sebuah jaringan kerja dan komunitas yang memungkinkan adanya kerja sama.

Modal sosial berdasarkan teori dinamika kelompok ini, menekankan pada aspek jaringan hubungan sosial yang diikat oleh kepemilikan informasi, rasa saling percaya, saling memahami, kesamaan nilai, dan saling mendukung. Modal sosial akan semakin kuat apabila sebuah komunitas atau organisasi memiliki jaringan hubungan kerja sama, baik secara internal komunitas/organisasi atau hubungan kerja sama yang bersifat antar komunitas/organisasi. Jaringan kerja sama yang sinergis yang merupakan modal sosial akan memberikan banyak manfaat bagi kehidupan bersama.Menurut Brehm dan Rahn dalam Ancok (2003, p.16), modal sosial merupakan jaringan kerja sama di antara warga masyarakat yang memfasilitasi pencarian solusi dari permasalahan yang dihadapi mereka. Menurut Feniger dkk (2005, p.9) pemanfaatan modal sosial dan modal budaya secara optimal me- lalui jaringan kerja sama antara sekolah dan keluarga siswa di sekolah berbasis agama ternyata berdampak pada prestasi akademik yang lebih baik dibandingkan dengan sekolah umum di Israel.

SMP Muhammadiyah 5 Surakarta sebagai satuan pendidikan merupakan sebuah komunitas yang memiliki tingkat kohesivitas yang tinggi. Tingkat kohesivitas yang ditandai dengan adanya hubungan sosial yang aktif dan baik diantara warga sekolah, dalam hal ini guru dan tenaga kependidikan, seperti layaknya sebuah keluarga besar yang mengikat mereka dalam sebuah jaringan kerja yang kompak. Sebuah jaringan kerja yang diikat oleh adanya saling kepercayaan dan kesamaan nilai dan norma yang mereka yakini sebagai sesuatu yang baik dan sesuai dengan tugas dan tanggung jawab sebagai pendidik dan tenaga kependidikan yang menyebabkan adanya kerja sama.

Berdasarkan identifikasi di sekolah terdapat jaringan kerja sama di antara guru dan tenaga kependidikan yang dilandasi rasa percaya dan kesamaan nilai/norma dalam melaksanakan dan mensukseskan semua kebijakan dan program SMP Muhammadiyah 5 Surakarta; dan hal ini merupakan sebuah modal sosial yang kuat yang dimiliki oleh SMP Muhammadiyah 5 Surakarta. Jaringan kerja sama yang sinergis ini merupakan modal sosial yang telah dimanfaatkan dan diberdayakan dalam rangka mendukung pelaksanaan kebijakan kurikulum pendidikan budi pekerti di SMP Muhammadiyah 5 Surakarta. Hal ini dikarenakan pendidikan budi pekerti sebagai bagian dari pendidikan karakter memerlukan dukungan dan kerja sama dari semua warga sekolah. Mengingat bahwa pendidikan budi pekerti dalam implementasinya harus diajarkan melalui proses pembelajaran secara kognitif di kelas, pembiasaan, dan keteladanan dalam lingkungan sekolah, sehingga keberhasilan pelaksanaan pendidikan budi pekerti membutuhkan keterlibatan dan kerja sama dari semua warga sekolah, khususnya guru dan tenaga kependidikan lainnya. Hal ini sesuai dengan pendapat Benninga, J.S, dkk. (2005, p.12), bahwa pendidikan budi pekerti melalui proses pembelajaran, keteladanan, pembiasaan, dan dirancang dengan serius dan baik berpengaruh terhadap prestasi akademik siswa. Hal ini karena adanya kerja sama yang baik antara sekolah, keluarga. dan masyarakat. 
Jaringan kerja sama yang baik di antara warga sekolah SMP Muhammadiyah 5 Surakarta (kepala sekolah, guru, tenaga administrasi, penjaga sekolah, security) yang dilandasi rasa percaya karena adanya nilainilai yang sama yang mereka anut. Setiap individu percaya dan melihat sendiri bahwa warga sekolah yang lain mempunyai kepedulian terhadap pendidikan budi pekerti di sekolahnya. Setiap individu akan terlibat dalam setiap aktivitas yang mendukung pendidikan budi pekerti, yang terdiri dari pembiasaan, keteladanan, dan proses pembelajaran. Setiap individu melakukan itu karena didasari karena eksistensinya sebagai manusia yang beragama Islam, sebagai orang Jawa yang harus mengimplementasikan nilai-nilai budaya Jawa dalam kehidupan peserta didik di sekolah karena sangat sesuai dengan konsep pendidikan budi pekerti, rasa tanggung jawabnya sebagai seorang guru yang memang berkewajiban untuk melaksanakan aktivitas pembelajaran dan pendidikan, terutama pendidikan moral/budi pekerti, dan sebagai komitmennya sebagai warga sekolah yang harus patuh dan taat yang dilandasi rasa tanggung jawab untuk melaksanakan segala perturan di sekolah, mensukseskan semua yang menjadi tujuan dan program sekolah maupun yayasan.

Terciptanya jaringan kerja sama yang baik di antara guru dan tenaga kependidikan dalam mendukung pelaksanaan pendidikan budi pekerti, selain didasari dan disebabkan kesamaan nilai-nilai dan norma yang diyakini sebagai pedoman sikap dan berperilaku, juga karena karakter yang dimiliki guru dan tenaga kependidikan yang memungkinkan adanya interaksi sosial dan kerja sama. Karakter yang dimaksud disini yaitu sifat-sifat keperibadian yang dimiliki guru dan tenaga kependidikan SMP Muhammadiyah 5 Surakarta yang mendukung interaksi sosial dan kerja sama. Sifat kepribadian yang melekat pada diri individu guru dan tenaga kependidikan SMP Muhammadiyah 5 Surakarta yang memungkinkan kerja sama yang baik dalam mendukung pelaksanaan pendidikan budi pekerti yaitu adanya pikiran positif pada orang lain, kemampuan berempati, sifat melayani, dan kebiasaan apresiatif.

Sifat-sifat keperibadian yang memungkinkan terjadinya kerja sama, seperti tersebut di atas, dikuatkan oleh teori kepribadian yang melihat bahwa munculnya suatu kelompok kerja yang kohesif baru akan terjadi kalau individu memiliki sifat kepribadian tertentu yang mendukung interaksi sosial. Sifat keperibadian tersebut menjadi bagian dari atau yang menumbuhkan modal sosial. Teori kepribadian ini, didukung oleh konsep "Kecerdasan Emosional" yang dikemukakan oleh Daniel Goleman, yang menjelaskan bahwa individu yang memiliki tingkat kecerdasan emosional yang tinggi, yang ciri-cirinya seperti kemampuan untuk memotivasi diri sendiri, bertahan menghadapi frustasi, mengendalikan dorongan hati dan tidak melebihlebihkan kesenangan, mengatur suasana hati, empati pada orang lain, menyebabkan seseorang akan mudah diterima dan bergaul dengan baik di masyarakatnya. Sehingga individu dengan sifat-sifat demikian akan mudah bekerja sama dalam komunitasnya, dan mempunyai tingkat produktivitas yang tinggi dalam hidupnya (Goleman, 1999, pp.45-48).

Berdasarkan paparan data di atas, dapat disimpulkan bahwa berdasarkan kesamaan nilai dan norma serta sifat-sifat keperibadian yang melekat pada individu-individu guru dan tenaga kependidikan yang telah menumbuhkan jaringan kerja sama yang baik, tidak hanya dalam hubungan kerja di antara guru dan tenaga kependidikan, tetapi telah menumbuhkan keterikatan hubungan dan komunikasi sosial yang baik dengan warga masyarakat atau komunitas sekitar sekolah. Interaksi dan komunikasi dilakukan dengan warga kampung sekitar sekolah, warga institusi sekolah yang lain yang terdekat, penjual wedangan, petugas parkir, penarik becak, pemilik dan pelayan toko-toko di sekitar sekolah, pedagang kaki lima, pemilik warung makan, bahkan pegawai institusi atau yayasan di sekitar sekolah. Interaksi dan komunikasi sosial yang baik, berdampak positif bagi pelaksanaan kurikulum pendidikan budi pekerti yang memang harus mendapat dukungan dari semua pihak, terutama masyarakat sekitar sekolah. Dampak positif tersebut di antaranya yaitu SMP Muhammadiyah 5 Surakarta sering menerima laporan baik langsung atau melalui telepon, diminta maupun tidak, terkait dengan tindakan siswa yang dianggap mengganggu ketertiban umum ataupun melanggar norma sosial kemasyarakatan.

Keterikatan hubungan dan komunikasi sosial yang baik dengan warga masyarakat atau komunitas sekitar sekolah juga dise- 
babkan oleh kebijakan sekolah yang memberikan tempat kepada warga masyarakat sekitar sekolah yang memenuhi persyaratan untuk menjadi guru dan tenaga kependidikan di SMP Muhammadiyah 5 Surakarta. Perekrutan tenaga pendidik maupun nonpendidik yang berasal dari warga sekitar sekolah telah menciptakan terjalinnya hubungan sosial yang baik yang mendukung pelaksanaan pendidikan budi pekerti di sekolah. Hubungan kemasyarakatan yang baik dari guru dan tenaga kependidikan yang berasal dari warga sekitar sekolah, ternyata berdampak positif, yaitu warga masyarakat semakin mempunyai kepedulian terhadap sekolah, terutama terkait dengan perkembangan perilaku siswa. Wujudnya dengan memberitahukan kepada pihak sekolah jika ada siswa yang mengganggu ketertiban umum atau melanggar peraturan sekolah seperti membolos sekolah, merokok, nongkrong di pinggir jalan, atau menegur siswa secara langsung jika memungkinkan. Biasanya warga sekitar akan menelepon guru dan tenaga kependidikan yang berasal berasal dari masyarakatnya atau menjadi tetangganya.

Rasa saling percaya, nilai-nilai yang diyakini bersama, yang menumbuhkan semangat kerja sama, sifat-sifat kepribadian positif, dan perekrutan tenaga pendidik dan tenaga kependidikan yang berasal dari masyarakat sekitar sekolah, merupakan modal sosial potensial yang dimiliki oleh SMP Muhammadiyah 5 Surakarta untuk mewujudkan visi misi sekolah, termasuk dalam mensukseskan pelaksanaan kurikulum pendidikan budi pekerti. Modal sosial inilah yang dimanfaatkan pihak sekolah dalam pelaksanaan kurikulun pendidikan budi pekerti. Kepala sekolah sebagai pemegang otoritas sekolah, harus dapat memberdayakan modal sosial tersebut yang mengarah pada harapan tercapainya tujuan pelaksanaan pendidikan budi pekerti, sebagaimana yang diinginkan oleh Pemerintah Kota Surakarta, dalam hal ini Dinas Pendidikan dan Kebudayaan Kota Surakarta. Upaya yang dilakukan pihak sekolah, yang dipimpin kepala sekolah SMP Muhammadiyah 5 Surakarta dalam memberdayakan modal sosial dalam pelaksanaan kurikulum pendidikan budi pekerti, di antaranya adalah pertama, dibuatnya peraturan sekolah baik yang diberlakukan pada siswa maupun tenaga pendidik dan kependidikan. Peraturan siswa di antaranya mengatur tentang kewajiban dan hak siswa, peraturan tentang pelanggaran siswa dengan segala konsekuensinya. Untuk peraturan tenaga pendidik dan tenaga kependidikan, diatur tentang hak dan kewajiban, tugas dan tanggung jawab serta berbagai konsekuensi pelanggarannya, untuk masing-masing individu yang telah disepakati dan menjadi milik bersama. Kedua, adanya kesepakatan dan komitmen kerja yang ditandantangani di atas meterai. Kesepakatan dan komitmen yang dimaksud yaitu komitmen dan janji untuk bersedia melaksanakan tugas mengajar dan sanggup menaati peraturan/tata tertib yang berlaku yang tercantum dalam kesepakatan tersebut. Ketiga, Mengingat pengangkatan guru dan karyawan tetap di yayasan Muhammadiyah harus memenuhi persyaratan yang telah diatur melalui peraturan yayasan Muhammadiyah.

Kebijakan sekolah seperti tersebut di atas, semakin menumbuhkan modal sosial yang selama ini telah terbentuk di SMP Muhammadiyah 5 Surakarta, yaitu rasa saling percaya, nilai-nilai yang diyakini bersama, yang membentuk jaringan kerja sama yang baik di antara warga sekolah dan dengan warga atau masyarakat sekitar sekolah. Guru dan tenaga kependidikan merasa mendapat balikan yang positif dari pihak sekolah yang berupa perasaan merasa dihargai, diperhatikan atas apa yang mereka lakukan selama ini serta rasa jaminan bahwa apa yang telah mereka yakini dan lakukan ada konsekuensinya bagi siapa saja yang melanggarnya. Menurut Schwartz (1994, pp.19-45), ada beberapa sifat pribadi yang menumbuhkan dan memperkuat modal sosial, di antaranya adalah kebiasaan apresiatif. Orang yang memiliki sifat apresiatif ini suka memberikan apresiasi pada apa yang dilakukan oleh orang lain. Apresiasi yang diberikan pada orang lain membuatnya merasa dihargai.

Ada suatu hal yang semakin menumbuhkan rasa bermakna, sekaligus memperkuat modal sosial pada guru dan tenaga kependidikan di SMP Muhammadiyah 5 Surakarta, yaitu unsur ketaladanan yang ditunjukkan kepala sekolah sebagai implementasi atas berbagai peraturan sekolah yang telah diyakini sebagai norma. Unsur keteladanan yang meliputi kedisiplinan dalam melaksanakan tugas dan tanggung jawabnya sebagai guru dan pemimpin. Kebiasaan kepala sekolah yang selalu berkeliling di seluruh kelas pada jam pertama pelajaran untuk melihat apakah 
ada guru yang belum hadir untuk melaksanakan proses pembelajaran. Menurut Schwartz, orang yang memiliki sifat melayani akan menumbuhkan modal sosial (1994, p.45).

Pemberdayaan Modal Budaya dalam Pelaksanaan Pendidikan Budi Pekerti di SMP Muhammadiyah 5 Surakarta

Kultur Sekolah Berbasis Budi Pekerti dan agama merupakan modal budaya utama yang dimanfaatkan dan diberdayakan dalam mewujudkan keberhasilan pelaksanaan kurikulum Pendidikan Budi Pekerti di SMP Muhammadiyah 5 Surakarta. Terbangunnya kultur sekolah berbasis budi pekerti dan agama, mengingat bahwa SMP Muhammadiyah 5 Surakarta merupakan sekolah Islam yang didirikan oleh organisasi Muhammadiyah, sehingga segala kegiatan dalam proses pembelajaran dan pendidikan harus berlandaskan nilai-nilai Islam sesuai dengan visi dan misi organisasi Muhammadiyah, termasuk pelaksanaan kurikulum Pendidikan Budi Pekerti. Oleh karena itu, berbagai kegiatan rutinitas atau pembiasaan yang sudah menjadi kultur sekolah yang dimanfaatkan atau sengaja dibangun dalam mendukung pendidikan budi pekerti sangat bernuansa Islami.

Terbangunnya kultur sekolah berbasis budi pekerrti dan agama tidak bisa dilepaskan dari peran kepala sekolah dalam memelihara nilai, norma, yang diyakini warga sekolah, orang tua/wali murid, dan warga masyarakat sekitar sekolah, yang sejiwa dengan nilai-nilai budi pekerti. Nilai dan norma sebagai orang muslim, sebagai guru dan tenaga kependidikan, serta sebagai orang Jawa yang tidak bisa dilepaskan dari nilai-nilai budaya Jawa adiluhung yang memegang prinsip unggahungguh atau rasa hormat dalam bersikap, berperilaku, dan berbicara. Peran yang dimainkan kepala sekolah tersebut, pada intinya adalah dengan melakukan pembiasaan, keteladanan, dan pembelajaran pendidikan budi pekerti. Ketiga hal tersebut, pada dasarnya identik dengan pendapat Peterson dan Deal (Darmiatun, 2013, p.31) yang menyatakan bahwa Kepala sekolah dapat memainkan perannya dalam membangun budaya sekolah dalam bentuk melakukan pembinaan secara terus menerus dalam hal pemodelan (modeling), pengajaran (teaching), dan penguatan karakter (reinforcing) yang baik terhadap semua warga sekolah (guru, siswa, dan karyawan). Pendapat Peterson dan Deal, juga didukung oleh Widyaningsih, Zamroni, dan Zuchdi (2014, p.189), yang menyatakan bahwa terbentuknya kultur sekolah sebagai suatu nilai (values) sangat dipengaruhi oleh kepala sekolah dalam melakukan pendekatan secara komprehensif melalui tindakan pembiasaan (program kegiatan dan pembelajaran) dan keteladanan terhadap semua warga sekolah, termasuk guru. .Semangat yang dimiliki kepala sekolah bagi terwujudnya budaya sekolah dengan karakter terpuji sangat berpengaruh terhadap iklim yang akan tercipta di lingkungan sekolahnya.

Peran yang dilakukan kepala sekolah SMP Muhammadiyah 5 Surakarta dalam membangun kultur sekolah berbasis budi pekerti dan agama secara lebih detail yang pada intinya sesuai dengan pendapat Peterson dan Deal di atas adalah melalui pemodelan (modeling). Pemodelan yang telah dilakukan kepala sekolah SMP Muhammadiyah 5 Surakarta, yaitu mengeluarkan berbagai peraturan dan kebijakan sekolah dalam rangka mendukung terwujudnya visi dan misi sekolah, termasuk kebijakan pendidikan budi pekerti yang dikeluarkan oleh pemerintah Kota Surakarta. Berbagai peraturan dan kebijakan sekolah sebelum dan sesudah dijalankan berusaha disosialisasikan kepada warga sekolah termasuk orang tua/wali murid untuk memperoleh masukan, kritikan, dan persetujuan diberlakukannya peraturan dan kebijakan sekolah tersebut. Selain itu, kepala sekolah juga mengadakan pembinaan kepada guru dan karyawan secara rutin seminggu sekali sebagai proses diskusi, evaluasi, sosialisasi, terkait berbagai peraturan, program sekolah yang telah dan mau diberlakukan. Sedangkan untuk khusus guru, setiap hari sebelum jam pelajaran sekolah dimulai, kepala sekolah menyediakan forum kepada para wakasek dan guru-guru untuk menyampaikan berbagai informasi dan masukan terkait dengan berbagai kegiatan yang telah dan akan dilaksanakan, dan evaluasi terhadap berbagai program/kegiatan yang sedang berjalan. Pertemuan/breafing ini juga untuk mengecek kehadiran para guru yang mengajar di jam pertama.

Untuk lebih memberikan kenyamanan dan kepercayaan bagi warga sekolah (guru) dalam menjalankan visi dan misi sekolah, tugas dan tanggung jawabnya, demi keberlangsungan kultur sekolah berbasis budi pekerti, 
maka diadakan kesepakatan kerja di atas materai yang berisi berbagai kesepakatan dan komitmen dengan berbagai konsekuensinya yang harus ditaati oleh guru. Kesepakatan dan komitmen yang dimaksud yaitu komitmen dan janji untuk bersedia melaksanakan tugas mengajar dan sanggup menaati peraturan/tata tertib yang berlaku yang tercantum dalam kesepakatan tersebut, seperti tidak terlambat mengajar dan menjalankan tugas sekolah yang diberikan sesuai tupoksi, tidak ada jam kosong mengajar (terutama kelas IX) kecuali ada tugas dinas dan keperluan lain yang sangat penting dengan persetujuan kepala sekolah, kesanggupan melaksanakan dan mendampingi siswa dalam menjalankan sholat berjamaah, selama jam kerja tidak akan memanggil nama guru dan karyawan lain dengan namanya secara langsung "tanpa diawali panggilan pak atau ustadz untuk teman sejawat pria dan bu atau ustadzah untuk teman sejawat wanita, menjaga kerja sama dan rasa gotong royong dalam melakukan kegiatan sekolah.Sebagai konsekuensinya, pihak sekolah bersedia memenuhi hak-hak guru, terutama masalah kesejahteraan guru yang selalu diperhatikan. Untuk itulah, secara berkala, biasanya setahun sekali guru akan dinaikkan honor mengajar perjam pelajaran.

Kedua, pengajaran (teaching). Pembelajaran Pendidikan Budi Pekerti disampaikan oleh guru BP melalui berbagai strategi pembelajaran yang disesuaikan dengan karakteristik materi nilai-nilai budi pekerti yang akan disampaikan kepada siswa. Diharapkan melalui strategi pembelajaran yang tepat dan sesuai, siswa dapat mengetahui, memahami, dan pada akhirnya memiliki kesadaran akan pentingnya nilai-nilai budi pekerti tersebut bagi kehidupannya. Strategi pembelajaran Pendidikan Budi Pekerti juga dilakukan melalui pembiasaan dan keteladanan di kelas.

Ketiga, penguatan lingkungan (reinforcing), berupa kegiatan-kegiatan yang sudah menjadi kebiasaan yang mengandung penanaman nilai-nilai budi pekerti serta melalui berbagai tulisan yang mengandung pesanpesan moral atau nilai budi pekerti yang ditempel atau diletakkan di dinding sekolah yang strategis atau yang bisa dengan mudah dibaca oleh para siswa maupun warga sekalah pada umumnya.

Melalui pemodelan, pengajaran, dan penguatan lingkungan, yang didasari sema- ngat dan kolaborasi semua warga sekolah, maka kultur sekolah berbasis budi pekerti dan agama di SMP Muhammadiyah 5 Surakarta akan tetap terpelihara dan dikembangkan secara terus-menerus.

\section{Pemberdayaan Modal Sosial dan Modal Budaya di SMP Kasatriyan 1 Surakarta}

Pemberdayaan Modal Sosial dalam Pelaksanaan Pendidikan Budi Pekerti di SMP Kasatriyan 1 Surakarta

SMP Kasatriyan 1 Surakarta sebagai satuan pendidikan merupakan sebuah komunitas pendidikan yang memiliki tingkat kohesivitas yang tinggi yang ditandai dengan adanya hubungan sosial yang aktif dan penuh kekeluargaan serta kebersamaan di antara warga sekolah, dalam hal ini guru dan tenaga kependidikan, seperti layaknya sebuah keluarga besar yang mengikat mereka dalam sebuah jaringan kerja yang kompak. Sebuah jaringan kerja yang diikat oleh adanya saling kepercayaan dan kesamaan nilai dan norma yang mereka yakini sebagai sesuatu yang baik dan sesuai dengan tugas dan tanggung jawab sebagai pendidik dan tenaga kependidikan yang menyebabkan adanya kerja sama.

Berdasarkan hasil identifikasi terdapat jaringan kerja sama di antara guru dan tenaga kependidikan yang dilandasi rasa percaya dan kesamaan nilai/norma dalam melaksanakan dan mensukseskan semua kebijakan dan program SMP Kasatriyan 1 Surakarta; dan hal ini merupakan sebuah modal sosial yang kuat yang dimiliki oleh SMP Kasatriyan 1 Surakarta. Jaringan kerja sama yang sinergis ini merupakan modal sosial yang telah dimanfaatkan dan diberdayakan dalam rangka mendukung pelaksanaan kebijakan kurikulum pendidikan budi pekerti di SMP Kasatriyan 1 Surakarta. Hal ini dikarenakan pendidikan budi pekerti sebagai bagian dari pendidikan karakter memerlukan dukungan dan kerja sama dari semua warga sekolah. Mengingat bahwa pendidikan budi pekerti dalam implementasinya harus diajarkan melalui proses pembelajaran secara kognitif di kelas, pembiasaan, dan keteladanan dalam lingkungan sekolah. Sehingga keberhasilan pelaksanaan pendidikan budi pekerti membutuhkan keterlibatan dan kerja sama dari semua warga sekolah, khususnya guru dan tenaga kependidikan lainnya. 
Jaringan kerja sama yang baik di antara warga sekolah SMP Kasatriyan 1 Surakarta (kepala sekolah, guru, tenaga administrasi, penjaga sekolah, security) yang dilandasi rasa percaya karena adanya nilai-nilai yang sama yang mereka anut. Setiap individu percaya dan melihat sendiri bahwa warga sekolah yang lain mempunyai kepedulian terhadap pendidikan budi pekerti di sekolahnya. Setiap individu akan terlibat dalam setiap aktivitas yang mendukung pendidikan budi pekerti, yang terdiri dari pembiasaan, keteladanan, dan proses pembelajaran. Mereka melakukan itu karena didasari karena eksistensinya sebagai manusia yang beragama, sebagai orang Jawa yang harus mengimplementasikan nilai-nilai budaya Jawa dalam kehidupan peserta didik di sekolah karena sangat sesuai dengan konsep pendidikan budi pekerti, rasa tanggung jawabnya sebagai seorang guru yang memang berkewajiban untuk melaksanakan aktivitas pembelajaran dan pendidikan, terutama pendidikan moral/budi pekerti, dan sebagai komitmennya sebagai warga sekolah yang harus patuh dan taat yang dilandasi rasa tanggung jawab untuk melaksanakan segala perturan di sekolah, mensukseskan semua yang menjadi tujuan dan program sekolah maupun yayasan.

Terciptanya jaringan kerja sama yang baik di antara guru dan tenaga kependidikan dalam mendukung pelaksanaan pendidikan budi pekerti, juga karena karakter yang dimiliki guru dan tenaga kependidikan yang memungkinkan adanya interaksi sosial dan kerja sama. Karakter yang dimaksud di sini yaitu sifat-sifat keperibadian yang dimiliki guru dan tenaga kependidikan SMP Kasatriyan 1 Surakarta yang mendukung interaksi sosial dan kerja sama. Sifat kepribadian yang melekat pada diri individu guru dan tenaga kependidikan SMP Kasatriyan 1 Surakarta yang memungkinkan kerja sama yang baik dalam mendukung pelaksanaan pendidikan budi pekerti yaitu adanya pikiran positif pada orang lain, kemampuan berempati, sifat melayani, dan kebiasaan apresiatif. Pertama, pikiran positif pada orang lain, guru dan tenaga kependidikan mempersepsikan pendidikan budi pekerti sebagai sebuah kebijakan mulia yang memang harus didukung sebagai seorang pendidik, sebagai orang yang beragama dan sebagai warga masyarakat, khususnya masyarakat Jawa yang harus memegang norma-norma/nilai-nilai budaya Jawa yang menekankan sikap unggah ungguh dalam bersikap, berperilaku, dan berbicara. Oleh karena itu, setiap guru dan tenaga kependidikan percaya bahwa guru dan tenaga kependidikan yang lain, dengan penuh kesadaran mau dan mampu secara aktif untuk berpartisipasi dan bekerja sama dalam mendukung pendidikan budi pekerti.

Kedua, kemampuan berempati, guru dan tenaga kependidikan menyadari bahwa budaya kekerasan di Kota Surakarta, khususnya kerusuhan Mei 1998 di Surakarta, yang sebagian besar guru dan tenaga kependidikan melihat kejadian tersebut dan terkena dampaknya, telah meresahkan, memberikan rasa tidak nyaman, dan merugikan masyarakat Surakarta dalam segala aspek kehidupan. Kebijakan pendidikan budi pekerti sebagai salah satu cara untuk mengatasi dan upaya mencegah budaya kekerasan harus diapresiasi dan didukung secara positif dengan bekerja sama demi keberhasilan pelaksanaan pendidikan budi pekerti.

Ketiga, sifat melayani, guru dan tenaga kependidikan SMP Kasatriyan 1 Surakarta berusaha untuk komitmen menjalankan tugas dan tanggung jawabnya sebagai seorang pendidik dan pengajar dengan sebaik-baiknya. Komitmen itu telah dibuktikan guru dan tenaga kependidikan untuk terlibat secara aktif dalam berbagai kegiatan dan program sekolah khususnya yang terkait dengan akhlak siswa, tanpa melihat dan membedakan kegiatan dan program tersebut untuk tujuan apa, sasarannya siapa, menguntungkan diri pribadi atau tidak. Hal ini mengingat warga sekolah SMP Kasatriyan 1 Surakarta cukup multikultural baik dari segi agama, status sosial ekonomi, status kepegawaian untuk guru dan tenaga kependidikan. Dalam hal ini, semua warga sekolah tanpa memandang perbedaan agama dan perbedaan yang lain, akan mendukung semua kegiatan sekolah yang berdampak baik kepada sikap dan perilaku siswa walaupun kegiatan tersebut dalam rangka merayakan hari besar agama tertentu. Dukungan tidak dalam hal mengikuti pelaksanaan peribadatan, tetapi dukungan demi lancar dan suksesnya pelaksanaan kegiatan. Sebagai contoh, dalam rangka menyambut bulan suci Ramadhan, diadakan pesantren kilat, acara buka bersama, Salat Tarawih, pengajian bersama yang melibatkan siswa, guru, dan tenaga 
kependidikan yang lain, maka guru dan tenaga kependidikan yang beragama selain Islam akan membantu dalam mempersiapkan sarana dan prasarana, konsumsi, dan meminta, mendorong serta mengawasi siswa untuk mengikuti kegiatan-kegiatan tersebut dengan baik.

Dapat disimpulkan bahwa berdasarkan kesamaan nilai dan norma sebagai orang yang beragama, dan orang Jawa serta sifatsifat keperibadian yang melekat pada individu-individu guru dan tenaga kependidikan yang telah menumbuhkan jaringan kerja sama yang baik, tidak hanya dalam hubungan kerja di antara guru dan tenaga kependidikan, tetapi telah menumbuhkan keterikatan hubungan dan komunikasi sosial yang baik dengan warga masyarakat atau komunitas sekitar sekolah. Interaksi dan komunikasi dilakukan dengan warga kampung sekitar sekolah, warga institusi sekolah yang lain yang terdekat, pemilik warung makan, pemilik dan pegawai foto copy, penjual cindera mata/kerajinan, dan warga sekitar sekolah. Interaksi dan komunikasi sosial yang baik, berdampak positif bagi pelaksanaan kurikulum pendidikan budi pekerti yang memang harus mendapat dukungan dari semua pihak, terutama masyarakat sekitar sekolah. Dampak positif tersebut di antaranya yaitu SMP Kasatriyan 1 Surakarta sering menerima laporan baik langsung atau melalui telepon, diminta maupun tidak, terkait dengan tindakan siswa yang dianggap mengganggu ketertiban umum ataupun melanggar norma sosial kemasyarakatan. Tindakan warga masyarakat sekitar sekolah tersebut menunjukkan adanya kepedulian dan rasa tanggung jawab terhadap pendidikan budi pekerti pada umumnya, terutama kurikulum pendidikan budi pekerti di sekolah.

Rasa saling percaya, nilai-nilai yang diyakini bersama, yang menumbuhkan semangat kerja sama, dan sifat-sifat kepribadian positif, merupakan modal sosial potensial yang dimiliki oleh SMP Kasatriyan 1 Surakarta untuk mewujudkan visi misi sekolah, termasuk dalam menyukseskan pelaksanaan kurikulum pendidikan budi pekerti. Modal sosial inilah yang dimanfaatkan pihak sekolah dalam pelaksanaan kurikulun pendidikan budi pekerti. Upaya yang dilakukan pihak sekolah, yang dipimpin kepala sekolah SMP Kasatriyan 1 Surakarta dalam memberdayakan modal sosial dalam pelaksanaan kurikulum pendidikan budi pekerti, diantaranya adalah membuat berbagai aturan (nilai, norma, dan kebiasaan) yang efektif yaitu peraturan sekolah baik yang diberlakukan pada siswa maupun tenaga pendidik dan kependidikan. Peraturan siswa diantaranya mengatur tentang kewajiban dan hak siswa, peraturan tentang pelanggaran siswa dengan segala konsekuensinya. Untuk peraturan tenaga pendidik dan tenaga kependidikan, diatur tentang hak dan kewajiban, tugas dan tanggung jawab serta berbagai konsekuensi pelanggarannya, untuk masingmasing individu yang telah disepakati dan menjadi milik bersama.

Ada suatu hal yang semakin menumbuhkan rasa bermakna, sekaligus memperkuat modal sosial pada guru dan tenaga kependidikan di SMP Kasatriyan 1 Surakarta, yaitu unsur keteladanan yang ditunjukkan kepala sekolah sebagai implementasi atas berbagai peraturan sekolah yang telah diyakini sebagai norma. Unsur ketaladanan yang meliputi kedisiplinan dalam melaksanakan tugas dan tanggung jawabnya sebagai guru dan pemimpin. Kebiasaan kepala sekolah yang selalu berkeliling di seluruh kelas pada jam pertama pelajaran untuk melihat apakah ada guru yang belum hadir untuk melaksanakan proses pembelajaran.

Pemberdayaan Modal Budaya dalam Pelaksanaan Pendidikan Budi Pekerti di SMP Kasatriyan 1 Surakarta

Kultur Sekolah Berbasis Budi Pekerti dan Multikultural merupakan modal budaya utama yang dimanfaatkan dan diberdayakan dalam mewujudkan keberhasilan pelaksanaan kurikulum Pendidikan Budi Pekerti di SMP Kasatriyan 1 Surakarta. Terbangunnya kultur sekolah berbasis budi pekerti dan multikultural mengingat bahwa warga SMP Kasatriyan 1 Surakarta memiliki beberapa perbedaan, seperti perbedaan agama (Islam, Kristen, Katholik, Hindu/Budha), status dan kedudukan pegawai (PNS, Guru/Pegawai Tetap Yayasan, Honorer/Guru atau Pegawai Tidak Tetap), dan status sosial ekonomi. Perbedaan inilah yang justru dilihat oleh pihak sekolah/ warga sekolah sebagai suatu solusi untuk mengatasi masalah dan bukan dijadikan masalah dalam mendukung visi misi sekolah, termasuk semua program dan kebijakan sekolah, khususnya pendidikan budi pekerti. Warga sekolah (guru dan tenaga kependidikan, termasuk kepala sekolah) khususnya da- 
lam konteks pendidikan budi pekerti, lebih melihat pada adanya persamaan di antara mereka dan persamaan dari berbagai perbedaan di antara warga sekolah SMP Kasatriyan 1 Surakarta. Persamaannya yaitu (1) sebagai orang Jawa dan mengabdi di sekolah dari yayasan milik dan berlokasi di sekitar Keraton Surakarta, mereka sangat memegang teguh nilai-nilai budaya Jawa yang berdasarkan prinsip kerukunan dan prinsip hormat, dengan unggah-ungguh/sopan santun dalam bersikap dan berperilaku di masyarakat yang jauh dari konflik atau kekerasan, (2) rasa tanggung jawab moral sebagai seorang guru yang harus melaksanakan tugas dan fungsinya sebagai pengajar dan pendidik. Sedangkan persamaan dari perbedaan di antara mereka adalah bahwa meskipun nilai-nilai sebagai pedoman bersikap dan berperilaku yang dianut warga sekolah berbeda-beda, tetapi ada benang merah ajaran yang sama dan diyakini oleh mereka, yaitu bahwa"siapa yang menanam kebaikan maka akan menghasilkan kebaikan "ngunduh" bagi diri sendiri pula", dan semua agama pasti mengajarkan kebaikan dalam hal akhlak atau budi pekerti dalam hubungan dengan sesama manusia. Penjelasan ini sesuai dengan konsep pendidikan budi pekerti yang menjelaskan bahwa pendidikan budi pekerti merupakan pendidikan nilai-nilai luhur yang berakar dari agama, adat istiadat dan budaya bangsa Indonesia dalam rangka mengembangkan kepribadian peserta didik supaya menjadi manusia yang baik. Dengan demikian, semua agama dan budaya Jawa sebagai bagian budaya bangsa Indonesia pasti mengajarkan nilai-nilai kebaikan yang menjadi acuan bagi pendidikan budi pekerti, khususnya di Surakarta (Soewandi dkk, 2005, pp.13-15).

Persepsi warga sekolah yang lebih melihat persamaan daripada perbedaan inilah yang mereka yakini sebagai sebuah norma warga sekolah dalam bersikap dan berperilaku untuk bekerja sama dalam suasana kebersamaan dan persaudaraan untuk mendukung dan melaksanakan pendidikan budi pekerti. Kerja sama antarwarga sekolah dalam melaksanakan program dan kebijakan sekolah yang lebih mengutamakan rasa kebersamaan dan persaudaraan, tanpa mempermasalahkan perbedaan inilah yang menjadi tradisi unik bagi SMP Kasatriyan 1 Surakarta, sehingga telah membentuk budaya sekolah berbasis budi pekerti dan multikulturalisme.
Kepala Sekolah SMP Kasatriyan 1 Surakarta yang memiliki otoritas sekolah, berusaha untuk membangun dan mengembangkan kultur sekolah yang berbasis budi pekerti dan multikultural tersebut. Kepala sekolah berusaha untuk melakukan pembinaan secara rutin dan terus menerus dalam hal pemodelan, pengajaran, dan penguatan karakter yang baik terhadap semua warga sekolah. Kepala sekolah berusaha bertindak menampilkan keteladanan bagi guru dan tenaga kependidikan, siswa, dan orang tua siswa. Secara teratur dan berkesinambungan kepala sekolah melakukan komunikasi dengan warga sekolah mengenai terwujudnya budaya sekolah yang berbasis budi pekerti dan multikultural tersebut. Kepala sekolah menyadari bahwa dengan warga sekolah yang cukup multikultural dengan berbagai perbedaan, maka komunikasi yang intensif harus terus dilaksanakan. Tindakan ini untuk tetap menjaga rasa toleransi yang telah menciptakan hubungan sosial yang mengutamakan keakraban dan kebersamaan, dengan lebih melihat adanya persamaan di antara merekan dan menghargai adanya perbedaan. Untuk itu, setiap hari Senin mimimal dua minggu sekali dilakukan pembinaan terhadap semua guru dan tenaga kependidikan dan pertemuan dengan orang tua murid secara rutin bersamaan dengan pengambilan raport. Pertemuan tersebut sebagai media mensosialisasikan berbagai program dan kebijakan sekolah yang akan dan sudah dilaksanakan serta berbagai informasi lain, untuk diketahui dan memperoleh masukan dari warga sekolah maupun orang tua siswa. Pertemuan tersebut sekaligus sebagai media dialog untuk membicarakan berbagai permasalahan di SMP Kasatriyan 1 Surakarta, termasuk Pendidikan Budi Pekerti.

Menurut Syafiq A. Mughni (Mahfud, 2006,pp.xiii-xiv) ada dua hal untuk mewujudkan pendidikan multikultural, yaitu dialog dan toleransi. Kedua hal inilah yang sebenarnya yang dimanfaatkan kepala sekolah SMP Kasatriyan dalam membentuk kultur sekolah berbasis budi pekerti dan multikultural, seperti dijelaskan di atas. Pertama, dialog. Dalam pendidikan multikultural, setiap peradaban dan kebudayaan yang ada, berada dalam posisi yang sejajar dan sama. Tidak ada kebudayaan yang lebih tinggi atau dianggap lebih tinggi dari kebudayaan yang lain. Dialog meniscayakan adanya persamaan dan kesamaan di antara 
pihak-pihak yang terlibat. Melalui dialog diharapkan terjadi sumbang pemikiran yang pada gilirannya akan memperkaya kebudayaan atau perbedaan yang bersangkutan. Dialog juga sangat penting untuk mencari titik temu antar kebudayaan dan perbedaan yang ada. Kebudayaan manusia pada dasarnya memiliki nilai-nilai yang sama. Yang berbeda hanyalah kemasannya saja. Dialog diharapkan dapat mencari titik-titik persamaan sambil memahami titik perbedaan antarkebudayaan. Bila semangat ini terbangun, maka akan terjalin relasi harmonis antarperadaban dan kebudayaan yang ada. Kedua, toleransi. Toleransi merupakan sikap menerima bahwa orang lain berbeda dengan kita. Dialog dan toleransi merupakan satu kesatuan yang tidak dapat dipisahkan. Bila dialog itu bentuknya, toleransi itu isinya. Toleransi tidak hanya diperlukan dalam tataran konseptual, tetapi juga pada tingkat teknis operasional.

Pemodelan yang telah dilakukan kepala sekolah tersebut, yang pada intinya menekankan pada aspek keteladanan dan menerapkan konsep pendidikan multicultural melalui dialog dan toleransi, terbukti mampu menciptakan situasi kerja yang nyaman dan kondusif bagi warga sekolah untuk melaksanakan tugas dan kewajibannya dengan baik dan tulus tanpa adanya unsur penekanan atau paksaan, ketakutan, dan ancaman. Kondisi ini juga tidak terlepas dari kebijakan kepala sekolah yang memperhatikan hak-hak dan kesejahteraan guru dan tenaga kependidikan lainnya. Hal ini membuat kenyamanan mereka tanpa adanya kekhawatiran bahwa hak-haknya akan dikurangi atau dihilangkan. Kepala sekolah mempunyai kemampuan untuk selalu memperhatikan hak-hak dan kesejahteraan mereka karena sekolah oleh pihak yayasan diberikan otoritas untuk mengelola keuangan secara mandiri. Dalam konteks ini, kepala sekolah cukup transparan dalam melaporkan pengelolaan keuangan sekolah. Apalagi kepala sekolah dianggap oleh guru dan tenaga kependidikan dianggap sebagai seorang pribadi dengan karakter/budi pekerti yang baik. Hal ini menunjukkan bahwa kepala sekolah telah menunjukkan sikap dan perilaku keteladanan yang baik sebagai salah satu unsur utama dalam pembelajaran budi pekerti, di samping unsur kebiasaan dan pengajaran.

\section{SIMPULAN DAN SARAN}

\section{Simpulan}

Budaya sekolah berbasis budi pekerti di SMP Muhammadiyah 5 Surakarta dan SMP Kasatriyan 1 Surakarta yang terbentuknya sangat dipengaruhi oleh modal sosial telah terbukti cukup efektif dalam menurunkan tingkat kenakalan dan meningkatnya kedisiplinan dan kepatuhan dikalangan pelajar. Keterlibatan dan kerja sama seluruh warga sekolah dengan didasari oleh nilai-nilai agama, nilai-nilai budaya Jawa, serta komitmen dan rasa tanggung jawab sebagai warga sekolah dan yayasan (trust, network,norm) yang akhirnya menumbuhkan modal budaya berupa budaya sekolah berbasis budi pekerti merupakan modal yang sangat kuat dalam ketercapaian tujuan pendidikan budi pekerti.

Hasil penelitian seperti tersebut di atas, akan mampu mengatasi permasalahan utama yang mendasari dikeluarkannya kebijakan Kurikulum Pendidikan Budi Pekerti di Kota Surakarta, yaitu mengatasi budaya kekerasan khususnya di kalangan pelajar. Pemanfaatan dan pemberdayaan modal sosial dan modal budaya dengan melibatkan seluruh warga sekolah dan warga atau masyarakat sekitar sekolah melalui terbentuknya budaya sekolah berbasis budi pekerti dan kultur komunitas yang mendukung pelaksanaan pendidikan budi pekerti telah mampu mengurangi tingkat kenakalan dan tindakan imoral, meningkatnya kedisiplinan dan kepatuhan di kalangan pelajar di SMP Muhammadiyah 5 Surakarta dan SMP Kasatriyan 1 Surakarta.

\section{Saran}

Sekolah sebagai satuan pendidikan tidak terlepas dari konteks sosialnya. Konteks sosial dalam arti masyarakat sebagai sebuah struktur sosial dimana masyarakat sekolah menjadi bagiannya. Oleh karena itu, satuan pendidikan di sekolah, khususnya SMP di Kota Surakarta, perlu menjalin komunikasi dan interaksi sosial, serta melibatkan warga atau masyarakat sekitar sekolah baik langsung maupun tidak langsung dalam berbagai kegiatan sekolah. Hal ini dimaksudkan agar warga atau masyarakat sekitar sekolah mempunyai kepedulian atau merasa menjadi bagian dari sekolah dengan menciptakan iklim yang kondusif bagi perkembangan peserta didik melalui keteladanan dan kepedulian terhadap akhlak/budi pekerti peserta didik. 
Kepala sekolah yang memiliki otoritas, harus mampu memanfaatkan dan memberdayakan komponen-lomponen modal sosial agar efektif dalam mendukung visi misi dan tujuan sekolah, khususnya pendidikan budi pekerti. Kepala sekolah dapat mengeluarkan berbagai kebijakan, program, yang pada intinya bertujuan menciptakan jaringan kerja sama yang baik diantara warga sekolah, warga sekolah dengan warga atau masyarakat sekitar sekolah, serta warga sekolah dengan orang tua/wali murid untuk mendukung pelaksanaan pendidikan budi pekerti. Karena keberhasilan pendidikan harus melibatkan sekolah, masyarakat, dan keluarga.

Budaya sekolah berbasis budi pekerti sebenarnya merupakan jawaban atas refleksi kelemahan pendidikan nilai pada umumnya, khususnya pendidikan budi pekerti, yang selama ini cenderung mengutamakan aspek kognitif melalui pembelajaran di kelas. Dalam pendidikan budi pekerti yang utama adalah aspek keteladanan, pembiasaan, dan pengkondisian lingkungan, dan hal ini sudah terimplementasikan dalam budaya sekolah berbasisi budi pekerti. Oleh karena itu, satuan pendidikan di sekolah, khususnya SMP di Kota Surakarta, budaya sekolah perlu ditumbuhkan dan dikembangkan yang disesuaikan dengan visi misi sekolah, karakteristik atau ciri kahas sekolah, situasi dan kondisi sekolah, sehingga akan muncul budaya sekolah berbasis budi pekerti, budaya sekolah berbasis multikultural, dan lain sebagainya.

Kepada satuan pendidikan di sekolah, khususnya SMP di Kota Surakarta, berdasarkan temuan penelitian ini, perekruten tenaga pendidik dan karyawan yang berasal dari warga sekitar sekolah dengan sifat-sifat kepribadiannya yang positif, ternyata cukup memberikan dampak yang positif dan kontribusi yang besar dengan kepedulian mereka terhadap pendidikan budi pekerti di sekolah. Meskipun penerimaan guru dan tenaga kependidikan yang berasal dari warga sekitar sekolah bukanlah sesuatu yang di rencanakan dan lebih karena faktor kebetulan dan hanya melalui seleksi administrasi serta skala kebutuhan tenaga pendidik dan tenaga kependidikan saja. Oleh karena itu, dalam perekrutan/penerimaan guru dan tenaga kependidikan dari warga sekitar sekolah, lembaga pendidikan yaitu pihak sekolah harus selektif, terutama dari aspek sikap dan perilaku dengan sifat- sifat kepribadian yang dapat menumbuhkan modal sosial seperti pergaulan sosial yang baik, simpati, aktif dalam kegiatan kemasyarakatan, religius, atau memiliki kecerdasan emosional yang baik, di samping syarat-syarat administratif/akademik.

\section{DAFTAR PUSTAKA}

Ancok, D. (2003, Mei). Modal Sosial dan Kualitas Masyarakat. Makalah disajikan dalam Pidato Pengukuhan Jabatan Guru Besar pada Fakultas Psikologi Universitas Gadjah Mada.

Benninga, J.S., et. al. (2005). The Relationship of Character Education Implementation and Academic Achievement in Elementary Schools. Journal of Research in Character Education, 1,1, p.19-32. ProQuest Education Journals.

Darmiatun, S. (2013). Pendidikan Karakter di Sekolah.Yogyakarta: Gava Media.

Feniger,Y., Shavit,Y., \& Ayalon,H (2005). Cultural Capital, Social Capital and Educational Achievement in Religious and Secular Education in Israel. Tel Aviv: Tel Aviv University.

Fukuyama, F. (2007). Trust: Kebajikan Sosial dan Penciptaan Kemakmuran. (Terjemahan Ruslani). Hamilton. Jakarta: Qalam

Goleman, D. (1999). Kecerdasan Emosional. (Terjemahan T. Hermaya). Jakarta: Gramedia

Mahfud, C. (2006). Pendidikan Multikultural. Yogyakarta: Pustaka Pelajar.

Miles \& Huberman. (1984). Qualitative Data Analysis: a Sourcebook of a New Methods. Baverly Hills: Sage Publications.

Moleong, L.J. (2007). Metodologi Penelitian Kualitatif. Bandung: Remaja Rosdakarya.

Muhadjir, N. (2011). Metodologi Penelitian. Yogyakarta: Rake Sarasin

Nasution. (1992). Metode Penelitian Kualitatif. Bandung: Remaja Rosdakarya. 
Pemerintah Kota Surakarta. (2004). Pendidikan Budi Pekerti Pada SMP di Kota Surakarta. Surakarta: Pemerintah Kota Surakarta.

Schwartz, S.H. (1994). Are there Universal Aspects in the Structure and Contents of Human Values?(Versi electronic). Journal of Social Issues, Vol 50 No. 4: pp.19-45.
Widyaningsih, T., Zamroni, Z., \& Zuchdi, D. (2014). Internalisasi dan Aktualisasi Nilai-Nilai Karakter pada Siswa SMP dalam Perspektif Fenomenologis. Journal Pembangunan Pendidikan: Fondasi dan Aplikasi.2014; Vol 2, No.2;p.189. 